\title{
УДК 65.012.8:338(477)..
}

\section{МІСЦЕ ЕКОНОМІЧНОЇ ДИПЛОМАТІЇ В СИСТЕМІ ЕКОНОМІЧНОЇ БЕЗПЕКИ ДЕРЖАВИ}

\author{
Рокоча В.В. ${ }^{1}$, Горбачук O.I. ${ }^{2}$ \\ ${ }^{l}$ д.е.н., професор кафедри міжнародних економічних відносин, Університет «КРОК», \\ м. Київ, вул. Табірна, 30-32, 03113, Україна, тел.: (044)-456-71-91, e-mail: virar@krok.edu.иа, \\ ORCID: 0000-0002-0467-856X \\ ${ }^{2}$ к.е.н, доцент кафедри міжнародних економічних відносин, Університет «КРОК», \\ м. Київ, вул. Табірна, 30-32, 03113, Україна \\ тел.: (044)-456-71-91, e-mail: OleksandrGI@krok.edu.ua \\ ORCID: 0000-0001-2110-3254, DOI: https://doi.org/10.31732/2663-2209-2019-53-110-118
}

\section{LOCATION OF ECONOMIC DIPLOMACY IN THE SYSTEM OF ECONOMIC SECURITY OF THE STATE}

\author{
Rokocha $V^{1}$, Horbachuk $\mathrm{O}^{2}$ \\ ${ }^{1}$ doctor of economics, professor of the Department of International Economic Relations, \\ «KROK» University, Kyiv, st. Tabirna, 30-32, 03113, Ukraine \\ tel.: (044)-456-71-91, e-mail: virar@krok.edu.ua, ORCID: 0000-0002-0467-856X \\ ${ }^{2}$ Ph.D (Economics), associate professor of the Department of International Economic Relations, \\ «KROK» University, Kyiv, st. Tabirna, 30-32, 03113, Ukraine \\ tel.(044)-456-71-91, e-mail: OleksandrGI@krok.edu.ua \\ ORCID: 0000-0001-2110-3254, DOI: https://doi.org/10.31732/2663-2209-2019-53-110-118
}

\begin{abstract}
Анотація. В умовах глобальних трансформацій, з огляду на зростання масштабів міжнародної економічної взаємоідї, збільшення ї учасників $i$ загострення конкурентної боротьби, зявилася необхідність в універсальному механізмові оперативного узгодження та врегулювання різних, інколи діаметрально протилежних економічних інтересів держав. Функиї такого механізму в сучасній міжнародній практиці виконує економічна дипломатія, інструменти якої успішно застосовуються для подолання барєрів на шляху міжнародної торгівлі, вирішення суперечок та зброї ринку, дотримання умов контрактів, забезпечення усіх сторін міжнародних економічих відносин максимально симетричною інформацією. У статті обтрунтовується факт системного впливу інструментів економічної дипломатії на інтенсивність міжнародних торговоінвестиційних потоків і відповідно на складові економічної безпеки держави. Зокрема в результаті здійсненого кореляційного, регресійного $i$ дисперсійного аналізу попередньо зібраних $i$ систематизованих первинних емпіричних даних, щзо проводився із застосуванням мультиплікативної моделі, доведено пряму позитивну залежність між дією інструментів економічної дипломатії та основними показниками зовнішньоекономічної діяльності Украӥни (експорт, імпорт, ПІІ). Виявлений зв'язок є статистично значущим. Цей факт може свідчити про безпосередній вплив політико-дипломатичного компоненту на зовнішньоекономічну та інвестиційно-інноваційну складові економічної безпеки Украйни а також про опосередкований вплив на інші складові, щзо має суттєво корегувати загальний інтегральний індекс рівня економічної безпеки України. Тобто зроблено перший крок у науковому розумінні характеру і степені впливу інструментів економічної дипломатіі на рівень економічної безпеки української держави. Ця наукова проблема вимагає подальших досліджень, але вже сьогодні, на основі отриманих авторами результатів, можна обтрунтовувати необхідність внесення до Методики розрахунку рівня економічної безпеки Украӥни політико-дипломатичного компоненту.
\end{abstract}

Ключові слова: економічна безпека держави, економічна дипломатія, теоретичні та емпіричні дослідження, первинні емпіричні дані, моделювання.

Формул: 6, рис.: 2, таб.: 2, бібл.: 14

Annotation. In the context of global transformations, in view of the growth of international economic cooperation, the increase in its participants and the intensification of competition, the need for a universal mechanism for operational coordination and settlement of various, sometimes diametrically opposed, economic interests of states appeared. The functions of such a mechanism in modern international practice are carried out by economic diplomacy, whose tools are successfully used to overcome the barriers to international trade, resolve disputes and weapons market, adhere to the terms of contracts, and provide all sides of international economic relations with as symmetrical information as possible. The article substantiates the fact of systematic influence of instruments of economic diplomacy on the intensity of international trade and investment flows and, accordingly, on a number of components of economic 
security of the state. In particular, as a result of the correlation, regression and dispersion analysis of pre-assembled and systematized primary empirical data carried out with the use of a multiplicative model, a direct positive correlation was established between the operation of instruments of economic diplomacy and the main indicators of foreign economic activity of Ukraine (export, import, FDI). The revealed link is statistically significant. This fact may indicate the direct influence of the political-diplomatic component on the external economic and investment-innovation components of Ukraine's economic security, as well as the indirect influence on other components, which should substantially adjust the overall integral index of the level of economic security of Ukraine. That is, the first step in the scientific understanding of the nature and degree of influence of instruments of economic diplomacy on the level of economic security of the state. This scientific problem requires further research, but today, based on the results obtained by the authors, it is possible to justify the necessity of making a political and diplomatic component to the Methodology of calculating the level of economic security of Ukraine.

Key words: economic security of the state, economic diplomacy, theoretical and empirical research, primary empirical data, modeling.

Formulas: 6, fig.: 2, tab: 2, bibl.: 14

Постановка проблеми. В умовах глобальних трансформацій, 3 огляду на зростання масштабів міжнародної економічної взаємодії, збільшення іiі учасників і загострення конкурентної боротьби, з'явилася необхідність в універсальному механізмові оперативного узгодження та врегулювання різних, інколи діаметрально протилежних економічних інтересів держав. Функції такого механізму в сучасній міжнародній практиці виконує економічна дипломатія, інструменти якої успішно застосовуються для подолання бар'єрів на шляху міжнародної торгівлі, вирішення суперечок та збоїв ринку, дотримання умов контрактів, забезпечення усіх сторін міжнародних економічних відносин.

Західними фахівцями на основі емпіричних досліджень доведено, що відкриття додаткового консульства в країні перебування пов'язане зі зростанням експорту в цю країну на 6-10 \%, а відкриття посольства має такий самий ефект, як зниження від 2 до 12 відсоткових пунктів адвалорного тарифу [1]. Наведені цифри вказують на високий рівень дієвості інструментів економічної дипломатії розвинених країн, відтак на важливість моніторингу та кількісної оцінки їх ефективності.

Виконуючи свої функції, економічна дипломатія виступає одночасно i як інструмент стимулювання світових товарно-інвестиційних потоків, і як фактор захисту національних інтересів та забезпечення економічної безпеки держав.

Аналіз останніх досліджень $\boldsymbol{i}$ публікацій. Основи економічної дипломатії як науки i міжнародної практики, ऑii роль i місце в сучасних міжнародних відносинах вивчали такі зарубіжні й вітчизняні вчені, як Н. Бейн і С. Вулкок [2], В. Вергун [3], Г. Каррон де ла Карр'єр [4], В. Щетінін [5] та ін. Емпіричні дослідження в галузі економічної дипломатії розпочав А. Роуз [6], продовжують науковий пошук М. Маурел і Е. Афман [7], Г. Крюсен i А. Лежур [8] та ін. Окремим прикладним аспектам ролі економічної дипломатії в системі економічної безпеки держави присвячені роботи таких учених, як: П. ван Бергейк і С. Мунс [9], В. Нижник [10], К. Фліссак [11] та ін. Проте наукові публікації на пострадянському просторі, що присвячені економічній дипломатії, носять переважно вузькогалузевий теоретичний характер і не дають відповіді на питання місця економічної дипломатії у створенні системи економічної безпеки держави, як цей вплив відображається на рівні економічної безпеки держав.

Формулювання цілей статmі. Мета статті полягає в емпіричній перевірці значущості впливу інструментів економічної дипломатії на основні показники зовнішньоекономічної діяльності держави, а звідси на складові іiі економічної безпеки.

Виклад основного матеріалу дослідження. Наукова гіпотеза, якою керуються автори у своєму дослідженні, полягає в тому, що інструменти економічної дипломатії, впливаючи на інтенсивність торгово-інвестиційних потоків, коригують загальний 
інтегральний індекс економічної безпеки держави. Це пов'язано 3 тим, що лібералізація зовнішньоекономічної діяльності може створювати загрозу економічній безпеці країни, якщо в іiі запровадженні порушується низка важливих принципів. Насамперед зовнішньоекономічна лібералізація не повинна випереджати внутрішню економічну діяльність, оскільки цим створюється зовнішній конкурентний тиск на національних товаровиробників i процес пристосування національного виробничого потенціалу до міжнародного конкурентного середовища ускладнюється, особливо в галузях, які випускають високотехнологічну, капіталомістку та наукоємну продукцію [12]. В умовах відкритої економіки економічна безпека держави грунтується на мінімізації збитків від дії негативних зовнішніх чинників, створенні сприятливих умов для розвитку економіки шляхом іii активної участі у світовому поділі чинників виробництва та зовнішньоекономічній діяльності, що відповідає національним економічним інтересам.. Відтак система економічної безпеки будь-якої країни має враховувати крім внутрішніх загроз нові глобальні ризики, які виникають в процесі зовнішньоекономічної діяльності [13].

Для емпіричної перевірки цього зв'язку авторами було розроблено алгоритм, який містить у собі збір та обробку емпіричних даних названих видів діяльності, їх кореляційно-регресійний та дисперсійний аналіз та застосовано ряд інших математичних розрахунків і моделей. Було зібрано дані по 28 країнах - економічних партерах України та згруповано їх у п'ять груп: країни - найбільші торгові партнери України (Білорусь, Сгипет, Індія, Італія, Казахстан, Китай, Німеччина, Польща, РФ, США, Туреччина, Туркменістан, Угорщина); країни - найбільші інвестори України (Австрія, Британія, Італія, Кіпр, Нідерланди, Німеччина, Польща, РФ, США, Франція, Швейцарія, Швеція); країни G-7 та Корея (Британія, Італія, Канада, Німеччина, США, Франція, Японія, Корея); суміжні країни (Білорусь,
Молдова, Польща, Румунія, РФ, Словаччина, Угорщина); країни - партнери України по ГУАМ (Азербайджан, Грузія, Молдова).

Усі ці країни мають 3 Україною постійні, довготривалі та плідні політикоекономічні зв'язки. Часові межі вибірки даних взято за період з 2004 по 2015 рік включно, тобто за 12 років. Що стосується дипломатичних інструментів, то вибірка даних була зроблена 3 часу встановлення дипломатичних відносин до 2015 року.

Першим кроком аналітичної обробки емпіричних даних став кореляційний аналіз. Його метою було виявлення лінійної залежності економічних показників: первинних результуючих залежних змінних $(y)$ від впливу інструментів економічної дипломатії факторних змінних $(x)$. Як первинні залежні змінні $(y)$ розглядалися обсяги (1) експорту товарів (y1), (2) імпорту товарів (у2), (3) залучених в Україну прямих іноземних інвестицій (ПІІ) (у3). Як інструменти економічної дипломатії факторні змінні $(x)$ - автори використали: рейтинг роботи іноземних посольств в Україні (х1) та українських посольств за кордоном (x2), кількість іноземних генеральних консульств в Україні (х3) та українських генеральних консульств за кордоном $(\mathrm{x} 4)$, кількість іноземних почесних консульств в Україні (х5) та українських почесних консульств за кордоном (х6), кількість візитів рівня глав держав до України (x7) та візитів українських президентів за кордон (х8), кількість візитів високого рівня до України (х9) та візитів українських високо посадовців (спеціальних посланників Президента України, голів ВР, прем'єрміністрів, керівників МЗС) за кордон (х10), кількість постійно діючих двосторонніх органів високого рівня (х11), кількість діючих угод (х12), чисельність української діаспори в країнах перебування (х13) та кількість українських громадських організацій в країнах перебування (х14).

За результатами лінійного кореляційного аналізу було виявлено статистично значущий зв'язок між 
інструментами економічної дипломатії і показниками 3 експорту (в середньому $\mathrm{r}=$ $0,8)$ та імпорту (в середньому $\mathrm{r}=0,7$ ); щодо ПІІ, то суттєвого зв'язку не виявлено (в середньому $\mathrm{r}=0,1)$. Отже, можна зробити висновок що інструменти економічної дипломатії справляють значущий вплив на зовнішньоторговельну безпеку держави, але в частині інвестиційно-інноваційної безпеки цей вплив $€$ незначним. Оскільки лінійна залежність є найпростішою і може мати певні похибки, первинні дані було обраховано 3 використанням методів виявлення більш складних (нелінійних) форм зв'язку.

Регресійний аналіз первинних змінних проводився в межах спеціально виведеної мультиплікативної експоненціальної моделі (1.1), в якій фігурували усі параметри досліджуваних даних, завдяки чому було отримано достовірні числові показники залежності як для усього об'єму даних, так i для кожного параметру окремо. Модель була перевірена на адекватність і стала базовою у дослідженні.

$$
y_{1}=\alpha \prod_{i=1}^{14} \beta_{i}^{x_{i}} .
$$

За результатами регресійного i дисперсійного аналізу, що був проведений на основі моделі (1.1), було отримано додаткові дані щодо зв'язку досліджуваних показників: для експорту $\left(y_{1}\right)$ він становить $23,854 \%$, для імпорту $\left(y_{2}\right)-20,033 \%$, для ПІІ $\left(y_{3}\right)-20,032 \%$, тобто у розглянутому часовому періоді зміна (варіація) досліджуваних економічних показників в межах 20\% залежить від зміни (варіації) виділених 14 факторів дипломатичного компоненту. Такі параметри зв'язку засвідчують наявність i значущість позитивної залежності первинних змінних та застосування в моделі оптимального переліку інструментів економічної дипломатії.

За допомогою базової моделі методом головних компонент визначено вагові коефіцієнти 14 факторних змінних (х) та на підставі отриманих результатів розроблено алгоритм визначення інтегрального індексу економічної дипломатії України. Перевірка алгоритму включала в себе: нормування та визначення вагових коефіцієнтів результуючих змінних (у) (табл. 1); розрахунок значення інтегральних індексів української економічної дипломатії для кожної 328 досліджуваних країн та значення субіндексів експорту, імпорту, ПII. Загальний же інтегральний індекс української економічної дипломатії було розраховано як середньозважену величину шляхом згортки значень субіндексів.

Вагові коефіціснти факторів

\begin{tabular}{|l|l|}
\hline \multicolumn{1}{|c|}{$i$} & \multicolumn{1}{|c|}{$a_{i}$} \\
\hline 1 & 0,044592 \\
\hline 2 & 0,042682 \\
\hline 3 & 0,070114 \\
\hline 4 & 0,059232 \\
\hline 5 & 0,144466 \\
\hline 6 & 0,100286 \\
\hline 7 & 0,090119 \\
\hline 8 & 0,055206 \\
\hline 9 & 0,068242 \\
\hline 10 & 0,046468 \\
\hline 11 & 0,107091 \\
\hline 12 & 0,049667 \\
\hline 13 & 0,053085 \\
\hline 14 & 0,068749 \\
\hline
\end{tabular}


Інтегральний індекс для експорту визначався за формулою:

$$
\begin{gathered}
I_{1}=\sum_{i=1}^{14} a_{i} x_{i}=0,044592 x_{1}+0,042682 x_{2}+0,070114 x_{3}+ \\
+0,059232 x_{4}+0,144466 x_{5}+0,100286 x_{6}+0,090119 x_{7}+0,055206 x_{8}+ \\
+0,068242 x_{9}+0,046468 x_{10}+0,107091 x_{11}+0,049667 x_{12}+ \\
+0,053085 x_{13}+0,068749 x_{14}
\end{gathered}
$$

для імпорту -

$$
\begin{gathered}
I_{2}=\sum_{i=1}^{14} a_{i}\left(y_{2}\right) x_{i}=0,046889 x_{1}+0,044880 x_{2}+0,073725 x_{3}+ \\
+0,062283 x_{4}+0,151907 x_{5}+0,105451 x_{6}+0,094761 x_{7}+0,058049 x_{8}+ \\
+0,020252 x_{9}+0,048862 x_{10}+0,112607 x_{11}+0,052225 x_{12}+ \\
+0,055819 x_{13}+0,072290 x_{14}
\end{gathered}
$$

для ПІІ -

$$
\begin{gathered}
I_{3}=\sum_{i=1}^{14} a_{i}\left(y_{3}\right) x_{i}=0,073198 x_{1}+0,116282 x_{2}+0,026908 x_{3}+ \\
+0,023721 x_{4}+0,015940 x_{5}+0,036598 x_{6}+0,114782 x_{7}+0,092256 x_{8}+ \\
+0,099363 x_{9}+0,105851 x_{10}+0,009336 x_{11}+0,075102 x_{12}+ \\
+0,083643 x_{13}+0,053822 x_{14}
\end{gathered}
$$

Нормування даних для всіх країн і за весь період здійснювалося за методом розмаху варіації, а вагові коефіцієнти результуючих змінних (у) розраховувалися за методом головних компонент (табл. 2).

Вагові коефіціснти результуючих змінних $\mathbf{y}_{1}, \mathbf{y}_{2}, \mathbf{y}_{3}$

\begin{tabular}{|l|c|c|c|}
\hline № & $\mathbf{y}_{\mathbf{1}}$ & $\mathbf{y}_{\mathbf{2}}$ & $\mathbf{y}_{\mathbf{3}}$ \\
\hline 1 & 0,100127 & 0,046889 & 0,073198 \\
\hline 2 & 0,1001 & 0,04488 & 0,116282 \\
\hline 3 & 0,100005 & 0,073725 & 0,026908 \\
\hline 4 & 0,100006 & 0,062283 & 0,023721 \\
\hline 5 & 0,050003 & 0,151907 & 0,01594 \\
\hline 6 & 0,050014 & 0,105451 & 0,036598 \\
\hline 7 & 0,040185 & 0,094761 & 0,114782 \\
\hline 8 & 0,060453 & 0,058049 & 0,092256 \\
\hline 9 & 0,020379 & 0,020252 & 0,099363 \\
\hline 10 & 0,080914 & 0,048862 & 0,105851 \\
\hline 11 & 0,100004 & 0,112607 & 0,009336 \\
\hline 12 & 0,01474 & 0,052225 & 0,075102 \\
\hline 13 & 0,18096 & 0,055819 & 0,083643 \\
\hline 14 & 0,002112 & 0,07229 & 0,053822 \\
\hline
\end{tabular}

На основі отриманих результатів та 3 використанням статистичного аналізу кількісних показників 14 факторів (інструментів економічної дипломатії) щодо 28 країн світу (основних партнерів за період 2004-2015 рр.) розраховано субіндекси за основними показниками результативності зовнішньоекономічної діяльності України:

Таблиця 2

загальний інтегральний субіндекс за експортом

$I_{\text {ексn }}=0,14645$

загальний інтегральний субіндекс за імпортом

$I_{i M n}=0,16592$

загальний інтегральний субіндекс за ПІІ $I_{\text {ПIII }}=0,19779$

Загальний інтегральний індекс української економічної дипломатії розраховувався як середньозважена 
величина шляхом згортки значень субіндексів експорту, імпорту, ПІІ за формулою:

$$
I_{\text {Ед }}=\sum_{j=1}^{3} k_{j} I_{j}
$$

де, $k_{j}$ - ваговий коефіцієнт, прийнятий за $\frac{1}{3} ; I_{j}$ - інтегральний індекс.

Звідси загальний інтегральний індекс української економічної дипломатії $I_{\mathrm{Eд}}=0,170039276$.

Оскільки сукупний внесок досліджуваних країн у загальний обсяг українського експорту, імпорту та залучених ПІІ становить $\approx 80 \%$, а період дослідження охоплює 25 років, то отримані індекси можна вважати універсальними i застосовувати їх як еталонні в економетричних розрахунках щодо ефективності української економічної дипломатії.

У перебігу дослідження також було проаналізовано динаміку щільності зв'язку між змінними (х) і (у) окремо за кожен рік i за увесь досліджуваний період. У результаті проведеного кореляційного аналізу найсуттєвіший зв'язок між $x$ i $y$ було зафіксовано в роботі зарубіжних $\mathrm{i}$ українських посольств (у середньому коефіцієнт кореляції $\mathrm{r}=0,9)$, українські консульства показують суттєво менший рівень щільності зв'язку - в середньому $\mathrm{r}=$ 0,2 проти середнього $\mathrm{r}=0,5$ щодо зарубіжних консульств. Щодо $y 3$ (ПII), тог отриманий результат виявив найнижчі значення кореляційної залежності. Отож, можна припустити, що інструменти офіційної економічної дипломатії можуть суттєво впливати на рівень зовнішньоторговельної безпеки, щодо інвестиційно-інноваційної безпеки, то такий вплив не виявлено.

При проведенні дослідження було звернено увагу на особливості транскордонного співробітництва як фактору взаємодії економічної дипломатії та економічної безпеки держави. Об'єктом цього аналізу стало транскордонне співробітництво в Єврорегіоні двохсторонні і багатосторонні міжнародні асоціації та об'єднання прикордонних адміністративно-територіальних одиниць України та держав Центральної і Східної Європи, зокрема міжнародна асоціація Карпатський Єврорегіон у складі 4 країн: Польща, Словаччина, Угорщина та Румунія. Результати аналізу свідчать про наявність позитивного статистично значущого зв'язку між змінними (x) i (y) практично за усіма групами країн і за усіма змінними (х). Шляхом вилучення було встановлено оптимальну групу країн для подальшого розвитку економічних i політико-дипломатичних відносин України на рівні транскордонного співробітництва: Польща, Румунія, Угорщина і доведено, що 3 діючих форматів транскордонного співробітництва Карпатський Єврорегіон є для України оптимальним i найбільш ефективним.

Подальший аналіз ролі інструментів економічної дипломатії у формуванні кожного 3 видів зовнішньоекономічної діяльності України у відносинах з групою досліджуваних країн на рівні двосторонніх відносин засвідчив кореляційні коефіцієнти близькі до $\mathrm{r}=1$. Отож, можемо говорити про прямий, суттєвий зв'язок між змінними (х) та (у) за кожен рік i за увесь період транскордонного співробітництва з названими країнами.

Результати отриманих розрахунків багато в чому збігаються з оцінкою західних фахівців, щодо дії інструментів економічної дипломатії в розвинених країнах. Звідси можемо припустити, що рівень розвитку країн не здійснює суттєвого впливу на ефективність використання дипломатичних інструментів при проведенні торгово-інвестиційної діяльності. Об'єм опрацьованих даних та перевірена на адекватність модель, за допомогою якої отримано ці результати, дають підстави стверджувати, що розрахована ступінь впливу інструментів економічної дипломатії на зовнішньоторговельну та інвестиційну діяльність української держави $\epsilon$ достатньою точною. Виходячи 3 цього, ми можемо припустити, що цей вплив суттєво і позитивно позначається на рівні інвестиційноінноваційної та зовнішньо торговельної складових економічної безпеки України. 
Структурно-логічну схему впливу інструментів економічної дипломатії на складові економічної безпеки України представлено на (рис.1).

Виходячи 3 проведеного дослідження, на рівень інвестиційної та зовнішньоторговельної складові економічної безпеки країни інструменти економічної дипломатії здійснюють прямий, суттєвий вплив; на енергетичну та фінансову складові - прямий i опосередкований вплив; на виробничу та макроекономічну складові - опосередкований; вплив на продовольчу, соціальну та демографічну складові економічної безпеки $є$ похідним від перелічених.

У ширшому розумінні це можна проілюструвати як зовнішньоекономічну діяльність держави 3 відкритою національною економікою, яка $\epsilon$ складовою світової економічної системи (рис.2).

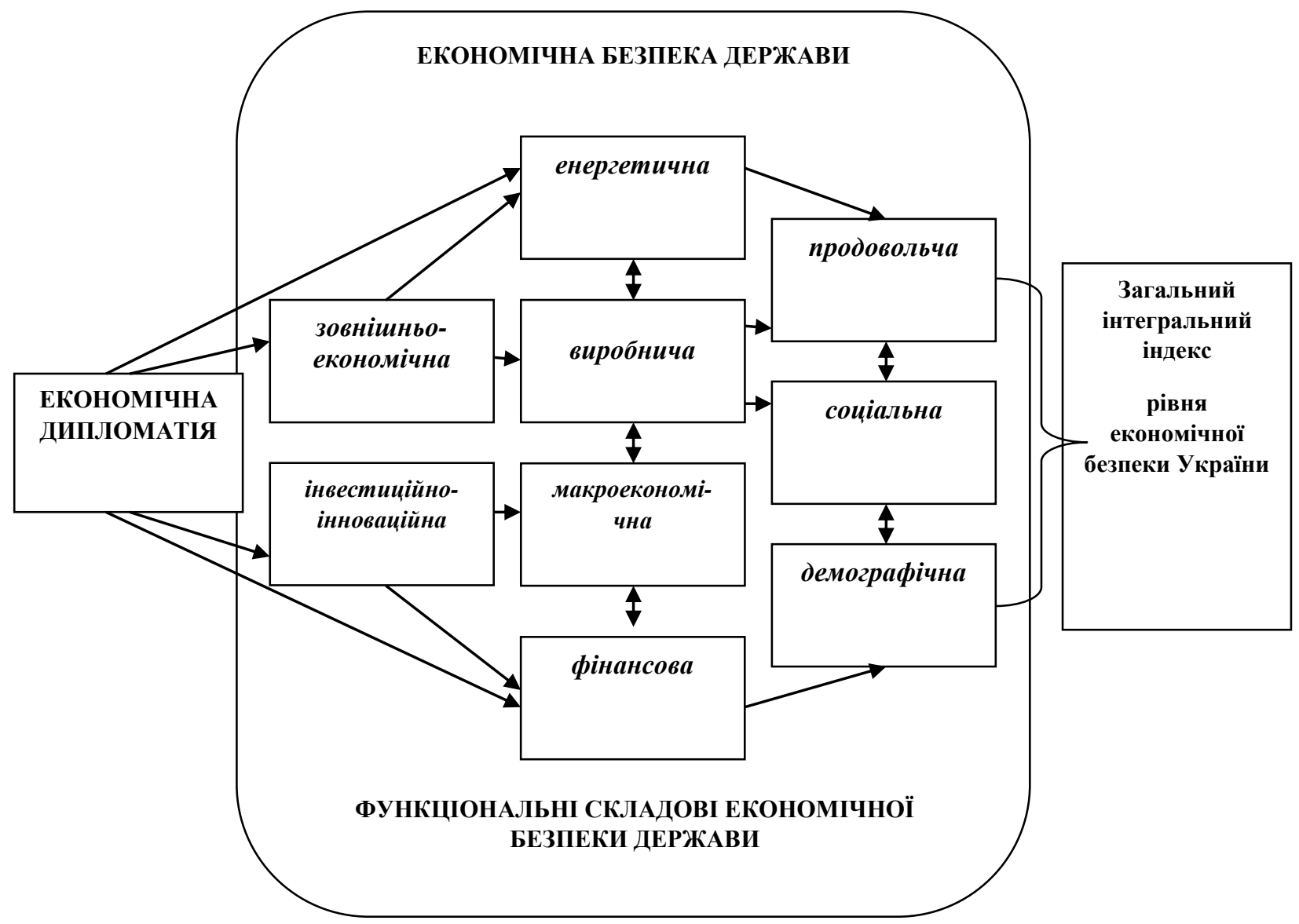

Рис. 1. Структурно-логічна схема впливу інструментів економічної дипломатії на складові економічної безпеки України

Висновки. Держава через політикодипломатичні важелі (інструменти економічної дипломатії) активно впливає на формування своїх основних показників зовнішньоекономічної діяльності: експорту, імпорту, ПІІ. Цей вплив, 3 огляду на результати наукового дослідження, є значущим, позитивним, що сприяе інтенсифікації товарноінвестиційних потоків. Звідси, відповідний позитивний вплив здійснюється на інвестиційно-інноваційну, зовнішньоекономічну і у великій мірі на енергетичну складові економічної безпеки держави. Потім відбувається взаємний вплив на рівні усіх складових, який в сукупності i формує стан економічної безпеки країни. Тобто $є$ підстави стверджувати, що економічна дипломатія шляхом прямих і опосередкованих впливів бере активну участь у формуванні інтегрального індексу рівня економічної безпеки України, що врешті відповідає національним інтересам держави i 
безпосередньо позначається на рівні і якості життя громадян [14].

Таким чином, зроблено перший крок у науковому розумінні значущості впливу інструментів економічної дипломатії на рівень економічної безпеки української держави. Ця наукова проблема вимагає подальших досліджень. Але вже сьогодні можна обгрунтовувати необхідність включення до методик розрахунку рівня економічної безпеки держави політикодипломатичного компоненту.

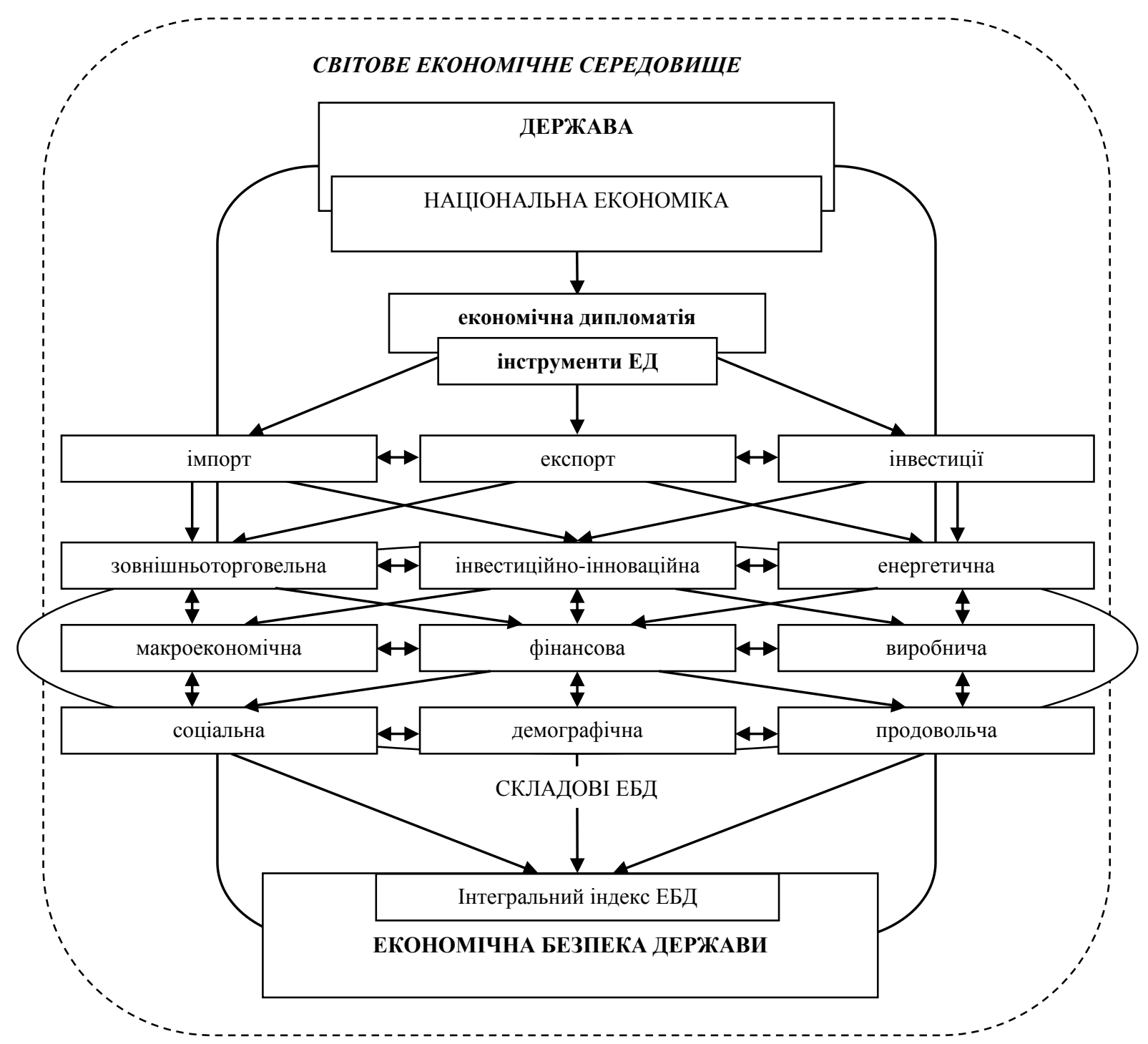

Рис. 2. Структурно-логічна схема впливу інструментів економічної дипломатії на рівень економічної безпеки української держави

\section{Jimepamypa:}

1. Peter A.G. van Bergeijk, Selwyn J.V. Moons, (2013) Economic Diplomacy Works: A meta-analysis of its effect on international economic flows. URL : http://www2.gre.ac.uk/_data/assets/pdf_file/0015/822 102/Selwyn-J.V.-Moons-and-Peter-A.G.-van-BergeijkEconomic-Diplomacy-Works-a-meta-analysis-of-itseffect-on-international-economic-flows.pdf.

2. Baine, N. and S. Woolcock, (2016) The New Economic Diplomacy: Decision Making and Negotiation in International Economic Relations, Ashgate Publishing Ltd. URL :
https://www.amazon.com/New-Economic-DiplomacyDecision-Making-International/dp/140942541X

3. Вергун В. А. Економічна дипломатія: навчальний посібник. Київ : Видавничополігрфічний центр «Київський університет», 2010. $303 \mathrm{c}$.

4. Ги Каррон де ла Каррьер. Экономическая дипломатия. Дипломат и рынок / Ги Каррон де ла Каррьер ; [перевод с франц. О.И. Пичугина]. Москва : «Российская политическая энциклопедия» (РОССПЭН), 2003. 296 с.

5. Щетинин В.Д. Экономическая дипломатия: Учебное пособие для вузов. Дипломат. акад. МИД 
России. Москва : Международные отношения, 2001. $280 \mathrm{c}$.

6. Rose, A.K., 2007, 'The Foreign Service and Foreign Trade: Embassies as Export Promotion', The World Economy, 30 (1), pp. 22-38. URL : http://www.nber.org/papers/w11111.pdf

7. Maurel, M. and E. Afman, "Diplomatic Relations and Trade Reorientation in Transition Countries" Paper presented at "The Gravity Equation Or: Why the World is not Flat" University of Groningen, 19 october 2007.

8. Creusen, H. and A. Lejour (2011), 'Uncertainty and the export decisions of Dutch firms', CPB discussion paper 183, The Hague. URL : http://www.cpb.nl/en/publication/uncertainty-andexport-decisions-dutch-firms

9. Economic Diplomacy and Economic Security by Peter A.G. van Bergeijk and Selwyn Moons URL : http://papers.ssrn.com/sol3/papers.cfm?abstract_id=14 36584

10. Нижник В. М. Економічна дипломатія та економічна безпека України : навчальний посібник Хмельницький : ХНУ, 2007. 299 с.

11. Фліссак К. А. Економічна дипломатія : навч. посіб. Тернопіль : «Новий колір», 2013. 440 с.

12. Бєлоусова I. А. Економічна безпека як стратегічна складова національної безпеки України URL : http://soskin.info/ea/2010/5-6/201036zmist.html

13. Рокоча В. В. Трансформація системи національної економічної безпеки в умовах глобалізації світової економіки. Зовнішня торгівля. Економічна безпека. Вип. 10. Київ, 2014. С. 71-77.

14. Горбачук О. I. Економічна дипломатія в забезпеченні економічної безпеки держави. Дисертація на здобуття наукового ступеня кандидата економічних наук зі спеціальності 21.04.01 - економічна безпека держави. Вищий навчальний заклад «Університет економіки та права «КРОК». Київ, 2017.

\section{Reference:}

1. Peter A.G. van Bergeijk, Selwyn J.V. Moons, (2013) Economic Diplomacy Works: A meta-analysis of its effect on international economic flows. Available at:

http://www2.gre.ac.uk/_data/assets/pdf_file/0015/822 102/Selwyn-J.V.-Moons-and-Peter-A.G.-van-BergeijkEconomic-Diplomacy-Works-a-meta-analysis-of-itseffect-on-international-economic-flows.pdf.

2. Baine, N. and S. Woolcock, (2016) The New Economic Diplomacy: Decision Making and Negotiation in International Economic Relations, Ashgate Publishing Ltd. Available at: https://www.amazon.com/New-Economic-DiplomacyDecision-Making-International/dp/140942541X.

3. Verhun, V. A. (2010) Ekonomichna dyplomatiia [Economic diplomacy], Vydavnychopolihrfichnyi tsentr «Kyivskyi universytet», Kyiv, Ukraine.
4. Guy Carron de la Carrière. Economic diplomacy. Diplomat and Market / Guy Carron de la Carrière; [translation from French O.I. Pichugin].

5. Shchetynyn, V. D. (2001) Эkonomycheskaia dyplomatyia [Economic diplomacy: textbook for universities], Moscow, Russia.

6. Rose, A. K. 2007 'The Foreign Service and Foreign Trade: Embassies as Export Promotion', The World Economy, 30 (1), pp. 22-38. Available at: http://www.nber.org/papers/w11111.pdf.

7. Maurel, M. and E. Afman, "Diplomatic Relations and Trade Reorientation in Transition Countries" Paper presented at "The Gravity Equation Or: Why the World is not Flat" University of Groningen, 19 october 2007.

8. Creusen, H. and A. Lejour (2011), 'Uncertainty and the export decisions of Dutch firms', CPB discussion paper 183, The Hague. Available at : http://www.cpb.nl/en/publication/uncertainty-andexport-decisions-dutch-firms

9. Economic Diplomacy and Economic Security by Peter A.G. van Bergeijk and Selwyn Moons Available at: http://papers.ssrn.com/sol3/papers.cfm?abstract_id=14 36584

10. Nyzhnyk, V. M. (2007) Ekonomichna dyplomatiia ta ekonomichna bezpeka Ukrainy [Economic diplomacy and economic security of Ukraine], KhNU, Khmelnytskyi, Ukraine.

11. Flissak, K. A. (2013) Ekonomichna dyplomatiia [Economic diplomacy], Novyi kolir, Ternopil, Ukraine.

12. Bielousova, I. A. (2010) "Ekonomichna bezpeka yak stratehichna skladova natsionalnoi bezpeky Ukrainy". Available at: http://soskin.info/ea/2010/5-6/201036zmist.html.

13. Rokocha, V. V. (2014) "Transformation of the system of national economic security in the conditions of globalization of the world economy", Zovnishnia torhivlia. Ekonomichna bezpeka, Vol. 10. pp. 71-77.

14. Horbachuk, O. I. (2017) Ekonomichna dyplomatiia $\mathrm{v}$ zabezpechenni ekonomichnoi bezpeky derzhavy. Abstract of Ph.D. dissertation, Global economy, «KROK» University, Kyiv, Ukraine.

Стаття надійшла до редакції 28.05.2019 р. 